\title{
POJETÍ STUDIA KŘESŤANSKÉHO VÝCHODU PODLE ANTONÍNA SALAJKY (1901-1975)
}

LUKÁŠ N O S E K

$P_{\text {ṙ }}$ redstavovaný autor Antonín Salajka se v roce 1930 stal prvním českým katolických knězem, který získal doktorát z východní teologie na římském Pontificio Istituto Orientale. Tuto skutečnost bychom chtěli náležitě reflektovat. Příspěvek se nejprve chce věnovat představení životního osudu Antonína Salajky (1.), chce krátce představit autorovo dílo se zaměřením na křesṫanský Východ (2.), podrobněji chce analyzovat samotné Salajkovo pojetí (včetně důvodů) ke studiu křestanského Východu, v neposlední řadě chce vynést na světlo autorovu smělou představu o zřízení Ústavu pro studium křestanského Východu při pražské teologické fakultě z konce 40. let 20. století (3.).

\section{1. Život Antonína Salajky ${ }^{1}$}

Náš autor pocházel z rolnické rodiny z Moravské Nové Vsi. Narodil se 25. dubna 1901. Obecnou školu v Moravské Nové Vsi ukončil v roce 1913. Následně navštěvoval Zemskou vyšší českou reálku v Hodoníně, kterou dokončil 2. července 1920 maturitou s vyznamenáním.²

1 Srov. Spisovna Katolické teologické fakulty UK (dále jen SKTF), osobní složka Antonín Salajka (3x); Centrum dějin české teologie při KTF UK, osobní fond Antonín Salajka (dále jen CDCT, fond AS I-V); NOSEK, Lukáš. Život a dílo Antonína Salajky (1901-1975). Prolegomena $k$ teologické analýze. Př́spévek $k$ déjinám katolické dogmatické teologie [rigorózní práce obhájená na KTF UK]. Praha, 2009, s. 7-106; NOVOTNÝ, Vojtěch. Katolická teologická fakulta 1939-1990. Prolegomena k déjinám české katolické teologie druhé poloviny 20. století. Praha: Karolinum, 2007, s. 388-389; www.cdct.cz.

2 Srov. SKTF, fond Personalia: sl. Antonín Salajka - 3x: Curriculum vitae jako př́loha žádosti o udělení veniae docendi ze dne 7. 11. 1937; CDČT, fond AS IV - Korespondence: kt. 2, sl. Různé: opis dopisu a pozvánky na sraz 40 let po maturitě, vč. jmen spolužáků a spolužaček ze dne 3. 7. 1960. 
Po maturitě podal přihlášku do pražského arcibiskupského semináře, kam byl přijat 31. srpna 1921, když zároveň s tím začal studovat pražskou bohosloveckou fakultu české univerzity. Protože neměl maturitu z řeckého ani latinského jazyka, doplňovací zkoušky ho čekaly v průběhu studia (16. záŕí 1922 z latiny na reálném gymnáziu v Uherském Hradišti; 2. října 1924 z řečtiny na Státním vyšším českém gymnáziu ve Strážnici na Moravě).

Je zajímavé, že již v pražském arcibiskupském semináři Salajka jevil velký zájem o tehdy aktuální velehradské unijní porady a kongresy. ${ }^{3}$ V semináři prý dokonce měl přezdívku „unionista“. 4 Tehdejší autorův zájem o velehradskou unionistickou myšlenku a o křestanský Východ dosvědčují i některé jeho studentské publikace. ${ }^{5}$

Bohosloveckou fakultu úspěšně zakončil 28. června $1925 .{ }^{6}$ Krátce na to byl 5. července vysvěcen arcibiskupem Františkem Kordačem na kněze. Od září 1925 sloužil jako kaplan a katecheta ve Velvarech, než dostal studijní volno na postgraduální studium do Říma na Papežský východní ústav (Pontificio Istituto Orientale), kam odešel na podzim roku 1927.7

3 Srov. GÓRKA, Leonard. Doktryna ekumeniczna Kongresów Welehradzkich (19071936). Studium z zakresu historii katolickiej myśli ekumenicznej. In MYŚKÓW, J. (ed.). Studia Ekumeniczne, sv. I. Warszawa: Akademia teologii katolickiej, 1982, s. 5-122; KOLEKTIV AUTORU゚. Fórum Velehrad I. Communio ecclesiarum - očišténi paméti. Olomouc: Refugium, 2007; TKADLČÍK, Vojtěch. Velehradská cesta k odloučeným bratřím. In Živá teologie 4, Praha: ČKCh, 1970, s. 41-68; TKADLČÍK, Vojtěch. Významní pracovníci velehradského unionismu. In KOLEKTIV AUTORŮ. Bohemia, Ecclesia, Universitas. Sbornik k osmdesátinám prof. Jaroslavu Kadlecovi. Praha: Karolinum, 1991, s. 173-182; AMBROS, Pavel. Velehrad. In FARRUGIA, Edward G. (ed.). Encyklopedický slovnik křestanského Východu. Olomouc: Refugium, 2010, s. 937-941. „... Ekumenismus není přece ,koníčkem‘ nějakého Salajky, kterému už v semináři dali přezdívku ,unionista‘, nýbrž jde o bytostnou otázku katolické Církve i ostatních křestanských církví, jde o pole, na němž by měli spolupracovat všichni dosud rozdělení křestané“ CDČT, fond Oto Mádr, sl. Teologická komise, kt. 1: Dopis Salajky Teologické komisi ze dne 7. 6. 1972.

5 Srov. SALAJKA, Antonín. Unionistický sjezd na posvátném Velehradě r. 1922. Museum 1922/23, roč. LIV, č. 1, s. 18-22; SALAJKA, Antonín. Sv. Josafat, mučedník unie. Museum 1923/24, roč. LV, č. 1-2, s. 16-19, 54-57; SALAJKA, Antonín. IV. unionistický sjezd na Velehradě. Museum 1924/25, roč. LVI, č. 1-2, s. 13-15, 49-54; SALAJKA, Antonín. Úkol katolických Slovanů (Výklad ideje cyrilometodějské). Museum 1924/25, roč. LVI, č. 5, s. $148-151$.

6 Curriculum vitae pro habilitační řízení, in: SKTF, fond Personalia, sl. Antonín Salajka; SAP, fond Osobní složky zemřelých kněží, sl. Antonín Salajka, kanovník - Opis životopisu ze dne 25. 1. 1971, AUK, fond KTF UK, FF UK.

7 Srov. CDČT, fond AS IV - Korespondence, kt. 1, sl. PIO; NOSEK, Lukáš. Život a dílo, s. 25-32. 
Pontificio Istituto Orientale (dále jen PIO) v Římě bylo založeno v roce 1917 Benediktem XV. ${ }^{8}$ Institut byl chápán jako projev zájmu římskokatolické církve o křestanský Východ. Jeho cílem byla výuka východních církevních věd (teologie, kanonického práva, liturgiky, církevních dějin a východní literatury a jazyků) v rámci minimálně dvouletého studijního programu (licenciát). Mezi úkoly institutu mj. patřily: rozšířit poznání křestanského Východu; teoreticky a prakticky připravit kněze, kteří šli působit do zemí křestanského Východu (diplomatické služby, řeholní zájmy...); umožnit postgraduální studium latinským kněžím východního obřadu; a v neposlední řadě výchova specialistů, kteří by studium dále šírili a předávali ve vlastních zemích. Papež chtěl, aby institut byl otevřen nejen pro studenty katolického vyznání, ale i pro východní křestiany, vč. pravoslavných. První profesorský sbor se skládal z řad diecézních i řádových kněží. V roce 1922 byl institut svěřen do péče jezuitů a v roce 1926 mu byla přidělena budova později sousedící s Papežskou ruskou kolejí (Russicum $)^{9}$ a Papežským ústavem křestanské archeologie nedaleko římské baziliky Santa Maria Maggiore. Podle našeho pátrání zde před Salajkou studovali pouze dva Češi (Josef Lepka SJ a p. Jaroslav Michalský). ${ }^{10}$ Další dva zde přednášeli: Bohumil Spáčil SJ, ${ }^{11}$ který vyučoval

8 Srov. BENEDIKT XV. Orientis catholici (motu propio ze dne 15. ř́ina 1917). AAS 1917, roč. 9, s. 531-533; BENEDIKT XV. Quod nobis (apoštolský list ze dne 25. září 1920). AAS 1920, roč. 12, s. 440-441; SALAJKA, Antonín. Papežský Východní ústav v Rímě. ČKD 1926, roč. LXVII/XCII, č. 3-4 a 9-10, s. 262-263 a 636; SALAJKA, Antonín. Papežský Východní Ústav v Římě. ČKD 1929, roč. LXX/XCV, č. 5-6, s. 528-537; SALAJKA, Antonín. Orientální ústav. In MERELL, Jan (a kol.). Malý bohovédný slovnik. Praha: ČKCh, 1963, s. 361-362; POGGI, Vincenzo. Papežský východní institut. In FARRUGIA, Edward G. (ed.). Encyklopedický slovnik, s. 676-678; POGGI, Vincenzo. Per la studia del Pontificio Istituto Orientale. Saggi sull'istituzione, i suoi uomini e l’Oriente Cristiano. Roma: PIO, 2000. K českým osobnostem viz ŠPIDLÍK, Tomáš. Čeští jezuité a slovanský Východ. In ALTRICHTER, Michal (a kol.). Velehrad filologoi versus filosofoi. Př́spěvek spirituálni teologie $k$ 800letému výroči. Olomouc: Refugium, 2005, s. 245-249; ČEMUS, Richard. Čeští jezuité na Orientálu. Jezuité2009, roč. XVIII, č. 1, s. 4-7.

9 Ruská papežská kolej a seminář založené Piem XI. v r. 1929 pro pomoc církvi v Rusku viz SIMON, Constantin. Pro Russia. The Russicum and Catholic Work for Russia. Roma: PIO, 2009; ČEMUS, Richard. Papežská ruská kolej svaté Terezie od Dítěte Ježíše (Russicum). In FARRUGIA, Edward G. (ed.). Encyklopedický slovnik, s. 672; ČEMUS, Richard. Papežská kolej Russicum. Teologické texty 1996, roč. 7, č. 2, s. 102-103.

10 Srov. Acta PIO 1920/21; SALAJKA, Antonín. Papežský Východní ústav. In ČKD 1926, s. 263; zatímco o Lepkovi jsme nalezli v Archivu PIO informace, o Michalském jakékoliv informace chyběly, zřejmě tu Michalský byl veden pouze jako tzv. studente ospite (hostující student).

11 Základní životopisné údaje viz AMBROS, Pavel. Spáčilovo ztracené Psallite regi nostro III nalezeno. Studia theologica 2006, roč. 8, č. 3 [25], s. 83-86; MADEY, Johannes. 
v l. 1917-1938 tzv. komparativní teologii; a Josef Vajs, který tu v r. 1922/23 vyučoval staroslověnštinu. ${ }^{12}$

Ze Salajkova římského studia se nám v Centru dějin české teologie dochovala poměrně rozsáhlá složka zápisů a skript. ${ }^{13}$ Mezi Salajkou navštěvovanými přednáškami byly mimo jiné: a) srovnávaci dogmatická teologie, b) východni patristika, c) historie rozkolu a východních církví, d) orientálni kanonické právo, e) orientální liturgie, f) úvod do studia křestanského V'́chodu, g) dogmatický a historický seminár. Vedle „Orientálu“ navštěvoval i Gregoriánskou univerzitu (kde poslouchal dva semestry apologetiku a historii dogmat) a Papežský biblický institut, ${ }^{14} \mathrm{kde}$ prohluboval znalosti $\mathrm{v}$ metodologii védecké práce. ${ }^{15}$ Pro zajímavost uved'me, že mu zde byl učitelem pozdější kardinál Augustin Bea. ${ }^{16}$

Za dobu svého studia Salajka postupně získal bakalaureát (r. 1927/28; prospěch: bene), licenciát (prolytatus, r. 1928/29; prospěch: cum laude) a závěrečný doktorát, který byl tehdy složený ze sepsání a veřejné obhajoby vědecké disertační práce. ${ }^{17}$ Disertační práci odevzdal z dogmatické teologie s názvem Doctrina theologiae Orientis separati de Christi redemptione, ${ }^{18}$ kterou obhájil a studia úspěšně ukončil 12. června 1930, čímž získal právo prokazovat se titulem ScEcclOrDr. ${ }^{19}$ Redakce Časopisu katolického duchovenstva ho následně označila

Spacil Theophil. In BAUTZ, Friedrich Wilhelm (ed.). Biographisch-Bibliographische Kirchenlexikon. sv. 16, Hamm: Verlag Traugott Bautz, s. 1451-1453; PAVLÍK, Jan. Budou vás vydávat soudům. Díl 2. Nekrology zemřelých členů české provincie T.J. $v$ době rozptýleni v letech 1950-1990. Praha: Societas, 1996, s. 5-7; POGGI, Vincenzo. Per la studia, s. 158-159; AMBROS, Pavel. Spáčil Bohumil SJ (1875-1950). In FARRUGIA, Edward G. (ed.). Encyklopedický slovnik, s. 840-841.

12 Srov. Acta PIO 1922/23; AMBROS, Pavel. Vajs Josef (1865-1959). In FARRUGIA, Edward G. (ed.). Encyklopedický slovnik, s. 931.

13 Srov. CDČT, fond AS III - Osobní dokumenty, kt. 2, sl. Skripta a zápisky/poznámky z PIO.

$14 \mathrm{~K}$ institutu viz PONTIFICIO ISTITUTO BIBLICO. Le persone del Biblico. Autorità, professori e studenti (1909-2009). Roma: PIB, 2009.

15 Srov. SKTF, fond Personalia: sl. Antonín Salajka - 3x: Curriculum vitae jako př́loha žádosti o udělení veniae docendi, ze dne 7. 11. 1937; CDČT, fond AS IV - Korespondence: kt. 1, sl. Zahraniční korespondence: dopis b. Neczeyovi ze dne 14. 3. 1964.

16 Srov. SCHMIDT, Stepjan. Augustin Bea. The Cardinal of Unity. New York: NY City Press, 1992.

17 Srov. Acta PIO 1928/29.

18 Srov. SALAJKA, Antonius. Doctrina theologiae Orientis separati de Christi redemptione [obhájená disertační práce na PIO]. Roma, 1930.

19 Srov. Acta PIO 1927/28-29/30; SKTF, fond Personalia: sl. Antonín Salajka - 3x: Curriculum vitae jako př́loha žádosti o udělení veniae docendi, ze dne 7. 11. 1937. 
jako prvního českého katolického kněze s doktorským titulem z východní teologie. ${ }^{20}$

Po svém návratu z Říma Salajka usiloval o doktorát i v Praze, který získal v r. 1936 (disertace Mista Písma svatého o vycházeni Ducha svatého se zvláśtním zřetelem k výkladu východnich odloučených theologũ). V letech 1931 až 1935 také absolvoval základní studium na Filosofické fakultě Univerzity Karlovy - to jako nutnou aprobaci pro středoškolské učitele. Po absolvování se stal na dlouhá léta středoškolským učitelem náboženství a katechetou v Praze (Vršovice a Karlín v letech 1935-1950), kde začal i pastoračně působit.

Následně v r. 1937 započal habilitační řízení na teologické fakultě v Praze, když jako svou habilitaci předložil mírně upravenou a do češtiny přeloženou disertační práci z Říma. ${ }^{21}$ Kvůli druhé světové válce bylo toto řízení úspěšně dokončeno až v r. 1945, když byl našemu autorovi udělen titul soukromý docent pro obor dogmatická orientální teologie a unionismus. Na pražské bohoslovecké fakultě začal krátce na to přednášet východní teologii a ruštinu (později východní teologii přednášel i na teologickém institutu v Brně). ${ }^{22}$ Po reformních změnách v bohovědných studiích v r. 1950 se sám nabídl (designovanému děkanovi fakulty Vojtěchu Šandovi a Státnímu úřadu pro věci církevní - dále SÚC) jako vyučující nově vypsaného předmětu církevní slovanština. Tím se zde stal profesorem a působil zde až do r. 1974. Vzápětí po reformních změnách začal suplovat dogmatickou teologii a později i krátce teologii morální. Od r. 1956 se stal jediným vyučujícím dogmatické teologie, až do příchodu doc. Václava Wolfa v r. 1969.

20 „Pisatel tohoto článku dosáhl 12. června 1930 doktorátu východní theologie na Papežském Východním Ústavě v Římě. Disertaci napsal ze srovnávací dogmatiky: Nauka theologie odloučeného Východu, zvláště ruské, o Kristově vykoupení. Vyložil v ní stručně nauku t. zv. knih symbolických, obšírněji nauku starších theologů, hlavně však názory theologů novějších a nejnovějších o různých otázkách při vtělení Syna Božího, o povaze a účelu vykoupení skrze smrt jeho na kříži, atd., srovnal ji s naukou katolickou a odchylné názory východních theologů podrobil příslušní kritice.“ (Je to prvý a dosud jediný doktorát východní theologie získaný katolickým knèzem naší republiky. Pozn. red.) In SALAJKA, Antonín. 50. výročí encykliky „Grande munus“(1880 30. IX. 1930). CKKD 1931, roč. LXXII/XCVII, č. 1, s. 1, pozn. 1.

21 Srov. SALAJKA, Antonín. Nauka východnich odloučených theologů, zvláště ruských, o Kristově vykoupeni. Praha: nákladem vlastním s podporou Akademie Velehradské, 1936.

22 Dochovaná zahajovací přednáška ze 23. 3. 1949 viz SALAJKA, Antonín. Úvod do studia křestanského východu. Část obecná (skripta pro posluchače CMBF). s.l., s.n., s.d. [1949], s. 1-9. 
V r. 1970 byl pak zvolen proděkanem. Po oficiálním odchodu do důchodu (r. 1971) mu byly uděleny ještě dva tzv. čestné roky, kdy přednášel staroslověnštinu a vedl k tomu i odborný seminář. Zkraje roku 1975 byl spolu s V. Bartůňkem, J. Kouřilem a J. Kubalíkem ustanoven sídelním kanovníkem kolegiální kapituly u Všech svatých na Hradě pražském. Od r. 1950 žil v klášterní věži u Pražského Jezulátka, odkud byl 2. srpna 1975 akutně převezen do Nemocnice pod Petř́nem, kde ještě téhož dne zemřel. Zádušní mši svatou sloužil v chrámu sv. Petra a Pavla na Vyšehradě tehdejší pražský arcibiskup František Tomášek. Pochován byl do kapitulní hrobky, kde je uložen s bývalými probošty kapituly a profesory fakulty: dr. Josefem Schindlerem (1833-1911), dr. Aloisem Soldátem (1862-1952), prof. Josefem Vajsem (1865-1959) a dr. Jaroslavem Kouřilem (1913-1981).

\section{Dílo s východokřestanskou tematikou}

V současné době čítá soupis Salajkou publikovaných děl (knihy, skripta, vědecké studie, recenze, popularizační články) přes 500 položek. Soupis těch nepublikovaných čítá něco kolem sta. ${ }^{23}$ Zde pouze krátce předložíme komentovaný přehled děl s východokřestanskou tematikou.

Souhrnem můžeme říci, že publikovaných položek, ve kterých se náš autor věnoval křestanskému Východu, je více jak polovina (cca 280). Vedle celé řady srovnávacích studií a studií věnujících se zpřístupňování ruské teologie ve specifických dogmatických otázkách (eschatologie, eklesiologie, christologie, soteriologie,...), ${ }^{24}$ se věnoval tehdejší ruské a obecně východokřestanské současnosti. ${ }^{25} \mathrm{~K}$ tomu je nutno připočíst

23 Srov. NOSEK, Lukáš. Život a dílo, s. 201-227.

24 Srov. SALAJKA, Antonín. 50. výročí; SALAJKA, Antonín. Nutnost a možnost nového ekumenického koncilu v odloučené Církvi řecko-ruské a nejnovější pokusy o jeho svolání. ČKD 1932, roč. 73/98, č. 7, s. 426-435; SALAJKA, Antonín. Fides et auctoritas ecclesiastica in conciliis oecumenicis. Acta Conventus Pragensis 1933, s. 168-186; SALAJKA, Antonín. Nauka východních odloučených theologů o posledních věcech člověka a světa. ČKD 1933, roč. 74/99, č. 1-2, s. 35-40, 117-129; SALAJKA, Antonín. Hlavní principy a známky pravoslavné církve. ČKD 1937, roč. 78/103, č. 5, s. 432-435; SALAJKA, Antonín. Spalování mrtvol a pravoslavná církev. Hlidka 1937, roč. 54, č. 7, s. 264; SALAJKA, Antonín. Věroučné rozdíly mezi pravoslavným Východem a katolickou Církví. ČKD 1938, roč. 79/104, č. 2, s. 150-154; SALAJKA, Antonín. Pojem (definice) církve u východních odloučených theologů. ČKD 1941, roč. 81/106, č. 5, s. 281-288; SALAJKA, Antonín. Autokefalie ruské pravoslavné církve. CKKD 1949, roč. 89/114, č. 1-2, s. 1-11; SALAJKA, Antonín. Velehradské unijni kongresy ve svétle ekumenismu. s.l., s.n., 1967.

25 Srov. SALAJKA, Antonín. Náboženské poměry v Rusku. ČKD 1926, roč. 67/92, č. 5-6, s. 357-361; SALAJKA, Antonín. Činnost sekt v Rusku. Lidové Listy 1927, roč. 6, č. 205 


\section{velkou porci recenzí na knihy s politickou tematikou tehdejšího SSSR,} v nichž si zvláště všímal těch věnujících se pronásledování pravoslavných křestanů. Recenzoval ale i knihy věnující se srovnávání bolševismu a nacismu s křestanstvím. ${ }^{26}$ Samostatně je třeba zmínit i jeho

(ze dne 6. září 1927) s. 5; SALAJKA, Antonín. Před svoláním všeruského pravoslavného koncilu v SSSR? Život 1936, roč. 18, č. 6, s. 53-54; SALAJKA, Antonín. Kongres pravoslavných theologů v Athénách. ČKD 1937, roč. 78/103, č. 4, s. 388-389; SALAJKA, Antonín. Pravoslavní theologové o svolání ekumenického koncilu. Hlídka 1937, roč. 54, č. 4, s. 159; SALAJKA, Antonín. Náboženská svoboda v Sovětském svazu podle nové ústavy. Hlidka 1937, roč. 54, č. 5, s. 188-189; SALAJKA, Antonín. Účast pravoslavných na interkonfesních sjezdech. Hlidka 1937, roč. 54, č. 6, s. 225-226; SALAJKA, Antonín. Pravoslavná církev v baltických státech. Hlidka 1937, roč. 54, č. 6, s. 226-227; SALAJKA, Antonín. Stolice pro bezboženství v Sovětském svazu. Hlidka1937, roč. 54, č. 9, s. 352; SALAJKA, Antonín. Encyklika Divini Redemptoris a sovětský tisk. Hlídka 1937, roč. 54, č. 9, s. 352; SALAJKA, Antonín. Z rumunské pravoslavné církve. Hlidka 1937, roč. 54, č. 10, s. 389-390; SALAJKA, Antonín. Náboženská „svoboda“v Sovětském svazu. Sursum 1937, roč. 17, č. 6, s. 190-191; SALAJKA, Antonín. Zeměpis obyvatelstva Sovětského svazu. Hlídka 1938, roč. 55, č. 6, s. 207; SALAJKA, Antonín. Třetí ruská pětiletka. Hlidka 1939, roč. 56, č. 2, s. 70; SALAJKA, Antonín. Vyhlídky křestanství na Dálném Východě. ČKD 1946, roč. 86/111, č. 1-2, s. 6-11, 46-51; SALAJKA, Antonín. Zřízení moskevského patriarchátu, jeho zrušení a obnova. Duchovni pastýr (dále jen DP) 1959, roč. 9, č. 4, s. 66-67; SALAJKA, Antonín. Cařihradský patriarchát. DP 1965, roč. 15, č. 2, s. 23-25; SALAJKA, Antonín. K událostem mezi Cařihradem a Římem. Katolické noviny 1966, roč. 18, č. 2 (ze dne 9. ledna 1966), s. 3; SALAJKA, Antonín. Přípravy pro všepravoslavný sněm. $D P 1973$, roč. 22, č. 3, s. 41-43.

Srov. SALAJKA, Antonín. (rec.) Trubeckoy Fürst Gregor, Die Glaubensverfolgung in Sowjetrussland. ČKD 1932, roč. 73/98, č. 1, s. 123-124; SALAJKA, Antonín. (rec.) Slavík Jan, Lenin. ČKD 1934, roč. 75/100, č. 8, s. 561; SALAJKA, Antonín. (rec.) Malý J., Křižz nad Evropou. Revoluce dvacátého století. ČKD 1936, roč. 77/102, č. 5, s. 515-516; SALAJKA, Antonín. (rec.) Stepun Fedor, Das Antlitz Russlands und das Gesicht der Revolution. ČKD 1936, roč. 77/102, č. 5, s. 518; SALAJKA, Antonín. (rec.) Lieb Fritz, Das geistige Gesicht des Bolschewismus. CKD 1936, roč. 77/102, č. 5, s. 518-519; SALAJKA, Antonín. (rec.) Normann Alfred Dr., Bolschewitische Welt macht politik. ČKD 1936, roč. 77/102, č. 2, s. 212; SALAJKA, Antonín. (rec.) Gide André, Návrat ze Sovětského svazu. ČKD 1937, roč. 78/103, č. 3, s. 295-296; SALAJKA, Antonín. (rec.) Mádle Josef, Orientem sovětů (Cestopis katolického kněze komunistickým SSSR), Nový Bydžov 1936. Rozpravy 1937, roč. 2, č. 9, s. 230-231; SALAJKA, Antonín. (rec.) Soloněvič Ivan, Rusko za mřižemi, Praha 1936. Rozpravy 1937, roč. 2, č. 9, s. 231; SALAJKA, Antonín. (rec.) Silberstein Leopold Dr., Výstavba národnostní kultury v SSSR, Praha 1937. Rozpravy 1937, roč. 2, č. 9, s. 232-233; SALAJKA, Antonín. (rec.) Le communisme et les chrétiens par Francois Mauriac, P. Ducattillon OP, Nicolas Berdiaeff, Al. Marc, D. de Rougemont, Daniel-Rops. Paris 1937. Rozpravy 1938, roč. 3, č. 2, s. 63; SALAJKA, Antonín. (rec.) Berdjaew Nikolai, Sinn und Schicksal des russischen Komunismus. Ein Betrag zur Psychologie und Soziologie des russischen Kommunismus. Luzern 1937. Rozpravy 1938, roč. 3, č. 5-6, s. 172; SALAJKA, Antonín. (rec.) Laski Harold J., Komunismus. Knihovna »Politika«, sv. 8, Praha 1938. Rozpravy 1938, roč. 3, č. 5-6, s. 173-174; SALAJKA, Antonín. (rec.) von Hippel Ernst, Der Bolschewismus und seine Ueberwindung, Breslau 1937. Rozpravy 1938, roč. 3, č. 5-6, s. 175; SALAJKA, Antonín. (rec.) Hippel von E., der Bolschewismus und seine Überwindung. ČKD 1938, roč. 79/104, č. 5, s. 436; SALAJKA, Antonín. (rec.) Berdjaew N., Sinn und Schicksal des russischen Komunismus. ČKD 1938, roč. 79/104, č. 5, s. 436-437; SALAJKA, Antonín. (rec.) Petit É., 
školské práce (dvě disertační a habilitační), které věnoval východní teologii. ${ }^{27}$ Zvláštní částí námi zmiňovaných příspěvků jsou ty, které se věnují staroslověnským otázkám (život sv. Cyrila a Metoděje, staroslovenský jazyk a písmo). ${ }^{28}$ Zde stojí za zmínku dodnes př́nosný Salajkou sestavený sborník k výročí smrti sv. Cyrila Konstantin-Kyrill aus Thessalonike z roku 1969 vydaný v tehdejší Německé spolkové republice. ${ }^{29}$ Jako dlouholetý učitel staroslověnštiny k ní také sepsal skripta, která však již dávno upadla v zapomnění. ${ }^{30}$ Jako slavista se věnoval spíše popularizačním příspěvkům a tématům. ${ }^{31}$

Historie de la Russie et de l'U. R. s. S.. ČKD 1938, roč. 79/104, č. 3, s. 285-287; SALAJKA, Antonín. (rec.) Vilinskij V., Ruská revoluce 1825-1936. ČKD 1938, roč. 79/104, č. 3, s. 287-288; SALAJKA, Antonín. (rec.) Le communisme et les chrétiens. ČKD 1938, roč. 79/104, č. 2, s. 190-191; SALAJKA, Antonín. (rec.) Bolschewistische Wissenschaft und "Kulturpolitik«. Ein Sammelwerk herangeg. Königsberg 1938. Rozpravy 1939, roč. 4, č. 10-11, s. 196; SALAJKA, Antonín. (rec.) Bolschewistische Wissenschaft und „Kulturpolitik“. ČKD 1940, roč. 80/105, č. 2, s. 158-159.

Srov. SALAJKA, Antonius. Doctrina; SALAJKA, Antonín. Nauka východnich odloučených theologů o vycházeni Ducha svatého. Studie biblicko-dogmatická [zamítnutá disertační práce na KTF UK]. Praha, 1933; SALAJKA, Antonín. Mista Písma svatého o vycházeni Ducha svatého se zvláštním zřetelem $k$ výkladu východních odloučených theologů [obhájená disertační práce na KTF UK]. Praha, 1935; SALAJKA, Antonín. Nauka východnich odloučených theologů, zvláště ruských, o Kristově vykoupení.

28 Srov. SALAJKA, Antonín. Prameny k dějinám sv. Cyrila a Metoděje. DP 1953, roč. 3, č. 6, s. 84-86; SALAJKA, Antonín. Předloha biblických textů staroslověnských. $D P$ 1954, roč. 4, č. 2, s. 22-24; SALAJKA, Antonín. Podíl sv. Cyrilla a Metoděje na překladu Písma svatého. DP 1955, roč. 5, č. 7, s. 124-125; SALAJKA, Antonín. Měli Slované písmo již před sv. Konstantinem - Cyrilem? DP 1955, roč. 5, č. 8, s. 146; SALAJKA, Antonín. VIII. kapitola staroslověnského života sv. Konstantina Cyrilla. DP 1955, roč. 5, č. 9, s. 163; SALAJKA, Antonín. Význam P. J. Šafaříka pro staroslověnský jazyk a písemnictví. DP 1961, roč. 11, č. 10, s. 183-185; SALAJKA, Antonín. Dva svátky tří světců. DP 1961, roč. 11, s. 46; SALAJKA, Antonín. Na okraj cyrilometodějského jubilea. $D P$ 1963, roč. 13, č. 1, s. 3-5; SALAJKA, Antonín. Myšlenka cyrilometodějská - pojítko slovanských národů. DP 1963, roč. 13, č. 5, s. 84-85; SALAJKA, Antonín. Základ a složky myšlenky cyrilometodějské. $D P 1963$, roč. 13, č. 7, s. 126-128; SALAJKA, Antonín. Magnifici eventus. DP 1963, roč. 13, č. 8, s. 142-143; SALAJKA, Antonín. Význam sv. Konstantina - Cyrila a Metoděje a jejich díla ve světle dnešního bádání. DP 1963, roč. 13, č. 9, s. 166-167; SALAJKA, Antonín. K pramenům o životě a působení soluňských bratří. DP 1963, roč. 13, č. 10, s. 185-186; SALAJKA, Antonín. K závěru cyrilometodějského výročí (863-1963). DP 1964, roč. 14, č. 1-2, s. 6-7, 28-29; SALAJKA, Antonín. Dvojí 1100. výročí (870-1970). DP 1971, roč. 20, č. 1-2, s. 4-5, 18-19; SALAJKA, Antonín. Slovanští misionáři v Čechách. DP 1975, roč. 23, č. 8, s. 116-117.

29 Srov. SALAJKA, Antonín (ed.). Konstantin-Kyrill aus Thessalonike. Würzburg: Augustinus-Verlag, 1969.

30 Srov. SALAJKA, Antonín. Úvod do studia staroslovénského jazyka a písemnictví. Praha: ÚCN, 1967.

31 Pokus o zhodnocení viz NOSEK, Lukáš. Portrét prof. Antonína Salajky jako slavisty (1901-1975). Ke 35. výročí úmrtí. Slovanské studie / Studia Slavica 2009, roč. 13, s. 229-239. 
Salajkův odborný přístup k východní teologii se po roce 1950 redukoval na zájem o církevní staroslověnštinu a o život a dílo slovanských věrozvěstů sv. Cyrila a Metoděje. Samostatně vydaných studií monografického charakteru z východního křestanství vydal jen několik, všechny před rokem 1950. V prvé řadě za zmínku stojí skripta Úvod do studia křestáanského Východu, ${ }^{32}$ vedle nich samostatné vydání třech přednášek s názvem Studium křestanského Východu. ${ }^{33}$ Oběma textům se budeme věnovat později. Odborná studie o sofiologii, christologii a soteriologii Sergeje Bulgakovova původně publikována v Časopisu katolického duchovenstva ${ }^{34}$ se dočkala také samostatného vydání. ${ }^{35}$ V neposlední řadě je třeba připomenout již zmíněnou habilitační práci. ${ }^{36}$ Pouze okrajově se věnoval východnímu křestanství v posledních letech svého života, kdy se zajímal o ekumenismus a promýšlel mnohá témata právě z této perspektivy. ${ }^{37}$

\section{Salajkovo pojetí studia křestanského Východu}

Než se budeme věnovat hlavní otázce naší studie, předložíme situaci ohledně studia křestanského Východu na pražské bohoslovecké fakultě v průběhu 20. století (3.1), poté představíme samotné př́istupy a důvody, které uváděl Salajka pro toto studiu (3.2) a nakonec představíme smělý pokus o založení Ústavu pro studium křestanského Východu při pražské bohoslovecké fakultě (3.3), čímž doplníme předcházející podkapitolu o praktický pohled.

32 Srov. SALAJKA, Antonín. Úvod do studia krestáanského východu.

33 Srov. SALAJKA, Antonín. Studium krestáanského východu. Praha: nákladem vlastním, 1948.

34 Srov. SALAJKA, Antonín. Názory ruského theologa s. N. Bulgakova o Sofii, vtělení a vykoupení Kristově. ČKD 1937, roč. 78/103, č. 3, s. 240-258.

35 Srov. SALAJKA, Antonín. Názory ruského theologa s. N. Bulgakova o Sofii, vtèlení a vykoupeni Kristové, Praha: nákladem vlastním, 1937.

36 Srov. SALAJKA, Antonín. Nauka východnich odloučených theologů, zvláště ruských, o Kristové vykoupení.

37 Srov. SALAJKA, Antonín. Velehradské; SALAJKA, Antonín. Ekumenické hledisko II. kapitoly dogmatické konstituce O církvi. Via. Časopis pro teologii 1969, roč. 2, č. 1, s. 8-10; SALAJKA, Antonín. Eucharistie a křest z ekumenického hlediska. In KOLEKTIV AUTORU゚. Krest. Přednášky z theologického kurzu pro kněze, 19.-22. 9. 1972. Praha - Litoměřice: CMBF, 1972, s. 52-56; SALAJKA, Antonín. Ekumenické smýšlení. In KOLEKTIV AUTORŮ. Sborník teologických kurzů pro knèze na CMBF, sv. IV - 1973 (18.-21. 9. 1973). Praha - Litoměřice: CMBF, 1973, s. 87-95. 


\subsection{K situaci výuky východního kréest'anství na pražské bohoslovecké fakultè ve 20. století}

Samostatné přednášky o křestanském Východu byly $\mathrm{v}$ obecném pohledu zařazeny do rámce povinného penza studia katolických bohoslovců v roce 1931 konstitucí Deus scientiarum Dominus. ${ }^{38}$ V českých zemích začala reforma teologického studia inspirovaná konstitucí po vleklých přípravách až schválením vládního nařízení 18. června roku $1937 .{ }^{39}$ Do procesu zavádění změn však přišla druhá světová válka s uzavřením vysokých škol a další kroky k celkové proměně studia byly odloženy. Finální zpracování a konečné schválení nových studijních předpisů římskou Kongregací seminářů a univerzit tak nastalo až v poválečném období, v květnu 1949.40

Na pražské bohoslovecké fakultě byly první otázky více či méně blízké křestanskému Východu probírány zvláště v rámci přednášek ze staroslověnštiny, které zde byly přednášeny od akademického roku 1912/13 tehdy soukromým docentem Josefem Vajsem. V rámci těchto přednášek se přednášející věnoval staroslověnské gramatice, četbě a výkladu staroslověnských biblických textů a v neposlední řadě i výkladu slovanské liturgie. Následně byl k tomuto předmětu od zimního semestru r. 1920/21 zř́zen seminář staroslověnské liturgie, který byl mj. zárukou pro školení ve vědecké práci v daném oboru. ${ }^{41} \mathrm{~V}$ průběhu dvacátých a třicátých let bychom neměli opomenout zdejší působení věhlasného byzantologa Františka Dvorníka, který se mezi lety 1925 až 1938 v rámci svých přednášek z církevních dějin jistě východnímu křestanství věnoval. ${ }^{42}$ V roce $1936 / 37$ pak ve výuce staroslověnštiny prof. Vajse nahradil prof. Josef Vašica, který zde církevní slovanštinu přednášel - vyjma období druhé světové války - až

38 Srov. AAS 1931, roč. 23, s. 241-262, 263-284 (česky: Apoštolská konstituce o universitách a fakultách pro církevní studia. ČKD 1936, roč. 77/102, č. 1, s. 33-48; Prováděcí nařízení k Apoštolské konstituci „Deus scientiarum Dominus“. ČKD 1936, roč. $77 / 102$, č. 2 , s. 111-132).

39 Srov. VAŇÁČ́, Martin. Katolická teologická fakulta Univerzity Karlovyv letech 1891-1939. Př́spèvek $k$ dèjinám vztahu mezi státem, církví a univerzitou na prelomu 19. a 20. stoleti [diplomová práce obhájená na KTF UK]. Praha, 1999, s. 89-90; NOVOTNÝ, Vojtěch. Katolická teologická fakulta 1939-1990, s. 61; KUDRNOVSKÝ, Alois. Bohovéda a jeji studium. Praha: Bohuslav Rupp, 1947, s. 62-102.

40 Srov. NOVOTNÝ, Vojtěch. Katolická, s. 43-143.

41 Srov. VAŇÁČ, Martin. Katolická, s. 91-92.

42 Srov. VAŇÁČ, Martin. Katolická, s. 141-143; NĚMEC, Ludvík. František Dvorník - mistr historické syntézy. Studie (1984) č. 91, s. 69-80; AMBROS, Pavel. Dvorník František (1893-1975). In FARRUGIA, Edward G. (ed.). Encyklopedický slovnik, s. 280-282. 
do r. $1950 .{ }^{43} \mathrm{~V}$ přednáškách a seminářích mezi lety 1950 až 1974 pokračoval Antonín Salajka, po němž se od r. 1977 výuce věnovala Markéta Koronthályová. ${ }^{44}$

Samotné přednášky o křestanském Východu byly v Praze vypsány až po druhé světové válce, kdy byl přizván k jejich přednášení námi studovaný autor. V srpnu 1950 byl na komunisty reorganizované pražské teologické fakultě pojmenované Římskokatolická cyrilometodějská bohoslovecká fakulta v Praze, uveřejněn prozatímní studijní řád, kde byl dosavadní předmět Úvod do studia křestanského Východu (část obecná a zvláštní) vynechán. Nepočítáme-li přednášky z církevních dějin, patrologie, liturgiky a církevní slovanštiny, kde se tématu křestanského Východu posluchač věnuje okrajově, situace se nezměnila prakticky až do roku 2007. V roce 2010 pak bylo na Katolické teologické fakultě UK zřízeno Centrum Pro Oriente Christiano, jehož posláním je právě mj. studium křestanského Východu (viz www.prooriente.cz).

\subsection{Jak pojímal studium křestáanského Východu Antonín Salajka?}

Na položený dotaz nejlépe dosáhneme odpovědi, když budeme sledovat Salajkovu reakci na výše konstatované zrušení inkriminovaných přednášek po státem provedených změnách bohovědných studií v r. 1950. Salajka Státnímu úřadu pro věci církevní adresoval deset důvodů, proč znovu zavést uvedené přednášky: ${ }^{45}$

(1) apoštolská konstituce o úpravě bohosloveckých studií Deus scientiarum Dominus z května 1931 zmiňuje tyto přednášky jako povinné, je tedy nutné je zavést;

(2) studium církevní slovanštiny je nemyslitelné bez doplňujících přednášek o křestanském Východu (k tomu ještě dodává: na území, kde sv. Cyril a Metoděj působili, jsou tyto přednášky povinností);

(3) studium přinese poznání ruské a obecně slovanské kultury;

(4) přednášky budou užitečné pro plné poznání katolické teologie: objasnění katolických článků víry, které se pozná jako důsledné rozvinutí patristického odkazu; proto má studium veliký význam i pro samotnou pravoslavnou teologii;

(5) studium poskytne prostředky pro unijní snahy (nejenom) s pravoslavnými křestany.

43 Srov. VAŇÁČ, Martin. Katolická, s. 120.

44 Srov. NOVOTNÝ, Vojtěch. Katolická, s. 321.

45 Srov. SKTF, fond Personalia: sl. Antonín Salajka - 3x: Salajkova žádost o zavedení přednášek o východním bohosloví, ze dne 3. 9. 1950. 
V tomto dopise Salajka ještě přiložil i program navrhovaných přednášek. Ty koncipoval do čtyř ročníků (podle čtyřletého reformovaného studijního plánu) a rozdělil je do třech bloků: I. Úvod do studia krestanského Východu (pro 1. a 2. ročník); II. Srovnávací dogmatické theologie (pro 3. a 4. ročník); III. Seminárni cvičeni z východního bohosloví (pro 3. a 4. ročník a doktorandy). ${ }^{46}$

Jako další krok k poznání autorova pojetí studia křestanského Východu nám poslouží několik klíčových textů. Brožura Studium křestanského východu je složena ze tří publikovaných prací. První dvě jsou upravené přednášky, které Salajka pronesl na unijním kurzu na Velehradě dne 12. srpna $1946 \mathrm{~s}$ názvem V'́znam studia křestáanského Výcho$d u$ (v brožuře na s. 3-11) a Organizace vědecké literárni práce unijni (s. 12-17). ${ }^{47}$ Jako třetí je sem přiložena upravená studie s názvem Bohosloví východnich křestanů (s. 18-31), která byla původně zveřejněna v nakladatelství Vyšehrad v řadě studijních textů. ${ }^{48}$ Pro náš úmysl je vhodné podrobněji pročíst přednášku první.

Nejprve k Salajkově charakteristice křestanského Východu. V těchto formulacích můžeme vidět vpravdě to nejlepší z velehradské tra-

46 I. Úvod do studia křestanského Východu - 1. Všeobecné poznatky o studiu křestanského Východu. 2. Vznik východních církví a obřadů. 3. Dějinný vývoj východních církví podle obřadů a jejich dnešní stav. 4. Ruská pravoslavná církev v dějinném přehledu. 5. Dokumenty o křestanském Východu, literatura o východních církvích a obřadech; II. Srovnávací dogmatická teologie - 1. Přehledný obraz katolického, pravoslavného a protestantského křestanského světa. 2. Katolické, pravoslavné a protestantské křestanství z věroučného hlediska. 3. Všeobecné poznatky o východním bohosloví. 4. Dějiny východního bohosloví, zvl. řecko-ruského. 5. Vybrané otázky z východního bohosloví (o vycházení Ducha svatého, o církvi, o Panně Marii, svátostech, o posledních věcech. 6. Katolické, pravoslavné a protestantské názory na jednotu Církve Kristovy; III. Seminární cvičení z východního bohosloví - 1. Dějinný vývoj dogmatu o Nejsvětější Trojici, zvláště na Východě. 2. Teologické názory a význam cařihradského patriarchy Fotia. 3. Nejstarší náboženská literatura ruská. 4. Cyrilometodějské otázky. 5. Věroučný rozbor církevně-slovanského písemnictví o sv. Cyrilu a Metodějovi. 6. Theologie sv. Cyrila a Metoděje. 7. Novější ruská christologie a soteriologie. 8. Názory ruského teologa A. s. Chomjakova a jeho škola. 9. Nauka ruského teologa s. N. Bulgakova o Sofii, vtělení a vykoupení Kristově a o církvi. - viz SKTF, fond Personalia: sl. Antonín Salajka - 3x: Salajkova žádost o zavedení přednášek o východním bohosloví, ze dne 3. 9. 1950.

47 Publikována i samostatně: SALAJKA, Antonín. Význam studia křestanského Východu. ČKD 1948, roč. 88/113, č. 1, s. 1-9 (rozšířená 1. část přednášky z Velehradu ze dne 12. 8. 1946); SALAJKA, Antonín. Organizace vědecké literární práce unijní. ČKD 1948, roč. 88/113, č. 2, s. 48-54 (2. část přednášky z Velehradu ze dne 12. 8. 1946).

Srov. SALAJKA, Antonín. Bohosloví východních křestanů. In CHUDOBA, Bohdan (ed.). Úvod do studia II. Bohosloví. Co a jak čist pro studium jeho jednotlivých oborů. Praha: Vyšehrad, 1946, s. 49-61. 
dice, jejímž „synem“ Antonín Salajka jednoznačně byl. ${ }^{49}$ „Musíme si uvědomit, že východni odloučené církve si uchovaly mnohé prvky puvodniho křestanství lépe než aktivni Západ.“ Nebo: „Mystické pojetí Církve v mnohém připadè vyjádrilla východni theologie lépe než západni (vyjímajíc sv. Augustina).“(s. 7-8)50

Vedle toho také uvedl dva důvody pro samotné studium křestanského Východu. První - který se neliší od jednoho z již výše uvedených důvodů - spočívá v hlubším poznání křestanské tradice. Což mj. přesvědčí studenta, že katolické bohosloví je důsledným rozvedením patristických koncilů a patristické teologie. A právě v tom viděl velký význam i pro samotné pravoslavné. ${ }^{51}$ Druhým důvodem je, že studium křestanského Východu a dějin jednotlivých východních církví nám poskytne prostředky pro unijní snahy. Vždyt „všechny sjednocovací snahy jsou bez důkladné znalosti křestanského Východu nemožné. 52

I zde předložil návrh studia, který rozdělil do čtyř částí:

(A) teologická část (studium jednotlivých dogmatických rozdílů vycházení Ducha Svatého, Filioque, očistec, prvenství a neomylnost římského papeže, látka eucharistie, epiklese, Neposkvrněné početí Panny Marie aj.; způsoby řešení těchto otázek jednotlivými autory obou tradic, vč. studia východní a západní patristiky);

(B) historická část (studium vzniku, příčin a vývoje církevního rozkolu; důraz na poznání jednotlivých církví, zvláště ruské);

49 K velehradské tradici např.: ZLÁMAL, Bohumil. Die Entwicklung der kyrillo-methodianischen Tradition in der Tschechoslovakischen Geschichte. In SALAJKA, Antonín (ed.). Konstantin-Kyrill, s. 77-157; AMBROS, Pavel. Svoboda k alternativám. Kontinuita a diskontinuita křestanských tradic. Olomouc: Refugium, 2008-2009, s. 484-507.

50 Srov. OE čl. 1; UR čl. 17; JAN PAVEL II. Orientale Lumen (apošt. list z 2. 5. 1995). AAS 1995 , roč. 87 , s. $745-774$.

51 „Studium křestanského východu je užitečné především k plnému poznání katolického bohosloví. Vede nás k studiu sv. Otců východních a církevních spisovatelů, $\mathrm{k}$ usnesení prvních církevních sněmů..., k starokřestanské bohoslužbě..., k počátkům mnišského a asketického života, jinými slovy k pramenům křestanské tradice, která jest spolu s Písmem sv. pramenem křestanské víry. Takovým studiem budou tím více objasněny katolické články víry a po diskusi s názory východních odloučených theologů o všech sporných otázkách bude shledáno, že se v ničem neodchylují od starokřestanského podání, nýbrž že jsou jeho důsledným rozvinutím. S tohoto hlediska má také studium křestanského Východu, zvláště z období prvních sedmi ekumenických sněmů (tj. doby před východním církevním rozkolem), veliký význam pro pravoslavné bohosloví، SALAJKA, Antonín. Význam studia křestanského Východu. In SALAJKA, Antonín. Studium, s. 9-10.

52 SALAJKA, Antonín. Význam, s. 9-10. 
(C) liturgicko-právnè-spirituální část (poznání východní liturgie, jednotlivých obřadů, kanonických sbírek, životopisů světců, zbožnosti a umění);

(D) církevni unionismus (studium všech problémů a obtíží snah po sjednocení včetně ekumenických hnutí v nekatolickém světě; hledání cest k jednotě; řešení způsobů, jak přiblížit odloučenému křestanskému světu katolické názory)..$^{53}$

$\mathrm{V}$ představované brožuře, přesněji v její druhé části (Organizace védecké literární práce unijni) pak mj. předložil konkrétní úkoly, které vzešly z porady pracovníků velehradského kongresu konaném v r. 1946. ${ }^{54}$ Ve třetí části (Bohoslovi východních křestanů) zase představil hutný bibliografický soupis literatury (cca 200 publikací z let 1860-1946) z nichž významné drobně okomentoval.

Dalším klíčovým textem pro zodpovězení otázky, jak Salajka pojímal studium křestanského Východu, jsou skripta Úvod do studia křest'anského Východu. Ćást obecná. Nejprve se opět věnujme charakteristice křestanského Východu. Salajka oproti předcházejícím textům, kde zdůraznil úlohu východních církví při uchování mnohých prvků původního křestanství, zde dodává, že tyto prvky musí být odkryty, aby byly ku prospěchu křestanského Západu. ${ }^{55}$ Jinde tento program doplňuje, když tvrdí: „Máme na mysli onu snahu a činnost Církve katolické, kterou od svého poćátku neustále vyvíjela a vyvijí, aby totiž privedla do svého mateřského náruči i ony krestany, kteři se od ní z rüzných př́ćin odloučili, at' už to jsou jednotlivci nebo veliké společenské celky.“" Nebo: „Církev katolická nikdy neopomenula vykonati vše, aby umožnila zbloudilým a od ní odloućeným nalézt cestu k návratu do jednoty svého církevního společenství... Kolikrát od doby církevního rozkolu se snaži-

53 Srov. SALAJKA, Antonín. Význam, s. 6-7.

54 „Bylo na ní usneseno vydati (během 2-5 let) základní spisy o křestanském Východu: Prameny cyrilometodějské a theologie sv. Cyrila a Metoděje (Dr. F. Grivec), Úvod do studia křestanského Východu (Dr. A. Salajka), Věrouka odloučeného křestanského Východu (Dr. I. Mastylak), Církevní právo východní (Dr. J. Jaroš), Dějiny doby cyrilometodějské (Dr. O. Polách), Dějiny ruské církve (Dr. J. Olšr), Úvod do studia slovanské bohoslužby (Dr. J. Vašica), Výtvarná kultura byzantské církve (Dr. J. Myslivec), Středověké církevní umění u Slovanů (Dr. J. Myslivec). Domníváme se, že kdyby se podařilo vydati uvedené spisy, že bychom hodně pokročili v poznání křestanského Východu a v šíření znalosti o něm. SALAJKA, Antonín. Organizace vědecké literární práce unijní. In SALAJKA, Antonín. Studium, s. 12-17 (zde 14-15). křestanství, které musí býti odkryty, aby byly ku prospěchu křestanského Západu.“ SALAJKA, Antonín. Organizace, s. 5. 
la Církev katolická uvésti východní odloučené krestany do svého lůna." $\mathrm{Z}$ těchto citací a termínů (např. návrat do lůna; návrat do mateřského náručí) můžeme poznávat Salajkou zastávaný dobový římskokatolický postoj tzv. návratu východních odloučených křestanů do církve katolické. 57

Podívejme se do Salajkova pojetí přednášek uvedených ve skriptech. Již ze samotného úvodu vyplyne rozdělení studia do dvou částí: obecné (pro 1. a 2. ročník) ${ }^{58}$ a zvláštní (pro 3. až 5. ročník). ${ }^{59}$ Přednášky obecné části pak rozdělil de facto do dvou bloků:

(1) prolegomena (snaha Církve katolické o jednotu; obecné poznatky o studiu krestanského Východu; vznik a vývoj východního církevniho rozkolu; príčiny východniho rozkolu podle recko-ruských déjepisců a teologů; doba po východním rozkolu a snahy o jednotu Církve);

(2) přehled východních církví podle liturgických obřadů60 (dèjiny a dnešni stav východnich odloučených i sjednocených církvi: východni cirkve byzantského obřadu; arménského obradu; syrského obradu; koptického obřadu; sjednocené církve východního obřadu; s. 58-191). ${ }^{61}$

56 SALAJKA, Antonín. Organizace, s. 1-2.

57 Srov. SMÍŠENÁ MEZINÁRODNÍ KOMISE PRO TEOLOGICKÝ DIALOG MEZI KATOLICKOU CÍRKVÍ A PRAVOSLAVNOU CÍRKVÍ. Uniatismus, unijní metoda minulosti a současné hledání plného společenství (dokument z Balamand z 23. 6 . 1993). In BUGEL, Walerian (ed.). Ekumenické konsensy I. Olomouc: Refugium, 2001, s. 85-102; BUGEL, Walerian. Ekleziologie Užhorodské unie a jejich dédiců na pozadí doby, Olomouc: Univerzita Palackého, 2003, s. 220-228.

58 I. Úvod do studia křestanského Východu (část obecná): 1. Obecné poznatky o studiu křestanského Východu. 2. Vznik a vývoj východního církevního rozkolu. 3. Východní rozkol podle řeckých a ruských dějin a teologie. 4. Snahu o obnovu církevní jednoty po východním rozkolu. 5. Dějiny a dnešní stav východních církví a obřadů (sjednocených o odloučených) - obsáhlou část zde zaujímají dějiny ruské pravoslavné církve od počátku až dodnes. 6. Přehled papežských dokumentů o křestanském Východu viz SALAJKA, Antonín. Úvod do studia křest́anského východu, s. 8.

59 II. Úvod do studia křestanského Východu (část zvláštní): 1. Dějiny řecko-ruského bohosloví. 2. Věroučné rozdíly mezi katolickou Církví a pravoslavným Východem a) nauka východních teologů o vycházení Ducha Svatého, b) nauka odloučených teologů o Církvi a prvenství v Církvi, c) nauka o svátostech (zvláště o kvašeném a nekvašeném chlebu při Svátosti oltářní, o epiklesi při mši svaté), d) nauka o Neposkvrněném početí Panny Marie, e) nauka o posledních věcech (o očistci a posmrtné odměně). 3. Nauka východních církví nestoriánských a monofysitských. 4. Cesty k jednotě Církve Kristovy - a) katolický názor na jednotu Církve, b) pravoslavné stanovisko k unijním a ekumenickým snahám, c) protestantské a anglikánské ekumenické hnutí viz SALAJKA, Antonín. Úvod do studia křestanského východu, s. 8.

60 K jinému typu dělení viz ROBERSON, Ronald. The Eastern Christian Churches. A Brief Survey, 6th edition, Roma: PIO, 1999; AMBROS, Pavel. Svoboda, s. 593-609.

61 Dále dělí: (A) Východní církve byzantského obřadu - VII. Byzantský obřad a církve byzantského obřadu; (A.1) Řekové - VIII. Řecké církve byzantského obřadu, IX. Církve melkitské (řecko-rabaské); (A.2) Slované - X. Ruská církev, XI. Srbská cír- 
Zvláštní části přednášek měl odpovídat i druhý díl skript. Přestože v osobním fondu Antonína Salajky při Centru dějin české teologie je celá řada rukopisů a příprav k nejrůznějším autorovým publikacím, texty, které by odpovídaly speciální části skript, zde nejsou (nepočítáme-li odborné studie k jednotlivým tématům publikované např. v Časopisu katolického duchovenstva, Hlídce, Apoštolátu sv. Cyrila a Metoděje).

Z výše řečeného rovněž vyplývá několik Salajkových pojetí studia křestanského Východu, která se vzájemně liší časovým rozložením:

(1) pojetí dvoublokové: (I. prolegomena: snaha Církve katolické o jednotu; obecné poznatky o studiu křestanského Východu; vznik a vývoj východního církevního rozkolu; příčiny východního rozkolu podle řecko-ruských dějepisců a teologů; doba po východním rozkolu a snahy o jednotu Církve; II. prehled východních církvi podle liturgických obraadi: dějiny a dnešní stav východních odloučených i sjednocených církví);

(2) trríblokové pojetí (I. Úvod do studia krestanského Východu; II. Srovnávaci dogmatické theologie; III. Seminární cvičení z východniho bohoslovi);

(3) čtyřblokové pojetí: (A. teologická část: studium jednotlivých dogmatických rozdílů; $B$. historická část: studium vzniku, příčin a vývoje církevního rozkolu; důraz na poznání jednotlivých církví; C. liturgickoprávnè-spirituální část: poznání východní liturgie, kanonických sbírek, životopisů světců, zbožnosti a umění; D. církevní unionismus: studium všech problémů a obtíží snah po sjednocení včetně ekumenických hnutí v nekatolickém světě; hledání cest k jednotě; řě̌ení způsobů, jak přiblížit odloučenému křestanskému světu katolické názory);

(4) na okraj je ještě třeba připomenout zásadní Salajkovo pojetí studia, které musí být chápáno v jasné návaznosti a souvislostech s přednáškami církevní slovanštiny.

kev, XII. Bulharská církev; (A.3) Rumuni - XIII. Rumunská církev; (A.4) Gruzíni XIV. Gruzínská církev; (A.5) Nové autonomní církve - XV. Národní církev v Albánii, XVI. Pravoslavná církev v Americe, XVII. Metropole pravoslavná v Estonsku, XVIII. Metropole pravoslavná ve Finsku, XIX. Pravoslavná církev v Polsku, XX. Pravoslavná církev v Litvě, XXI. Pravoslavná církev v Lotyšsku, XXII. Pravoslavná církev v ČSR, XXIII. Ostatní menší pravoslavné skupiny; (B) Církve arménského obřadu (monofysitské) - XXIV. Dějiny a církve arménského obřadu; (C) Církve syrského obřadu (monofysitské a nestoriánské) - XXV. Dějiny a církve syrského obřadu; (D) Církve koptického obřadu (monofysitské) - XXVI. Dějiny a církve koptického obřadu; (E) Sjednocené církve východního obřadu (katolické) - XXVII. Dějiny a dnešní stav sjednocených církví. 


\subsection{Snaha vytvořit Ústav studia křestáanského Východu v Praze}

Jestliže mapujeme Salajkovo pojetí a důvody ke studiu křestanského Východu je nutné představit - do jisté míry - unikátní „autorův projekt“, který díky politické situaci nedostál svého uskutečnění. Nejprve je třeba se zaměřit na Salajkovu žádost o jmenování mimořádným profesorem východní teologie z 25. dubna roku 1948. Již jsme poukázali, že jako profesorskou práci Salajka odevzdal své apologeticko-dogmatické pojednání o církvi s názvem Církev Kristova. ${ }^{62}$ Z odůvodnění, které k žádosti přiložil, plyne, že by měl být jmenován mimořádným profesorem východní teologie a zároveň by tím měla být zřízena nová stolice (pro východní teologii) na Bohoslovecké fakultě v Praze. Důvody proč jmenovat jeho a zároveň proč zř́dit novou stolici Salajka jasně propojuje, když říká mj. (1) jmenováním může být zř́zena nová stolice pro východní bohosloví a unionismus; (2) zřízení této stolice je naléhavé, jak z hlediska požadavku apoštolské konstituce Deus scientiarum Dominus, tak také díky tomu, že „zmènènými státoprávnimi poméry nastává bohoslovecké fakultě v Praze veliký úkol“[sic!]; ... (4) autor má připraven rukopis „velkého védeckého díla Církev Kristova“, kdy ho jako dvoudílný hodlá vydat v nakladatelství Vyšehrad; ... (7) závěrem zmínil svou osobní touhu zřídit na pražské bohoslovecké fakultě „jakési středisko pro studium křestáanského (zvl. slovanského) Východu“.63

V osobním fondu Antonín Salajky (při Centru dějin české teologie) se dochoval později sestavený koncept přípravy tohoto nového ústavu při pražské teologické fakultě. Předběžný název měl znít Ústav pro studium křestanského Východu při Bohoslovecké fakultèv Praze. Z tohoto konceptu vyplývá následující:

Hlavni zaméreni: (a) studium křestanského Východu; (b) cyrilometodějské otázky; (c) poznání východní liturgie; (d) ekumenismus; (e) unionismus; k tomu nutně připadala (f) znalost staroslověnštiny a dalších východních jazyků.

Forma studia: mělo jít o akademickou instituci při pražské bohoslovecké fakultě. Ústav měl vzdělávat několik typů posluchačů a v několika stupních. Šlo o (1) základní a (2) vyšší typ studia, které byly určeny

62 Srov. SKTF, sl. Fakultní rada - zápisy ze zasedání: 30. 4. 1948; Seznam osob a ústavů University Karlovy v Praze jakož $i$ státnich zkušebních komisí 1948. Praha: Akademický senát UK, 1948, s. 9-10.

63 Srov. SKTF, fond Personalia: sl. Antonín Salajka (3x) - Žádost o návrh na jmenování mimoř. profesorem pro stolici východního bohosloví, ze dne 25. 4. 1948. 
pro katolické bohoslovce, kněze i laiky. Vedle toho měl ústav pořádat cykly kurzů pro širokou veřejnost.

Organizačni struktura: v čele měl stát předseda a tajemník. Členy ústavu měli být odborně kompetentní profesoři fakulty. ${ }^{64}$

$\mathrm{Z}$ rešerše zápisů fakultní rady pražské bohoslovecké fakulty (50. až 70. léta) neplynou žádné další konkrétní informace o souvisejících aktivitách. Podobný úmysl zmínil náš autor ve studii o velehradských kongresech z druhé poloviny šedesátých let, ${ }^{65}$ kde napsal o ideji (původně prý z r. 1947) zřízení studijního střediska pro křestanský Východ v pražských Emauzích. Údajně vlivem společenských změn se tato intence neuskutečnila. ${ }^{66}$ Nakolik se tyto dvě ideje překrývaly, resp. byly navazující, není dosud zcela jisté. V tuto chvíli je pouze jasné, že k uskutečnění návrhů nedošlo.

\section{Závèr}

Závěrem se ještě nabízí následující otázka. Jak to je obecně s recepcí Salajkových odborných studií, skript a dalších příspěvků s tématem křestanského Východu v kontextu dobové i současné teologie. Pro nesystematické studium této problematiky odpovíme pouze zevrubnè. Co se týče dobové teologie je velmi potěšující, že v roce 1950 profesor Pontificio Istituto Orientale p. Maurizio Gordillo SJ Salajku parafrázoval v souvislosti se soteriologickým modelem zadostiučinění (satisfactio) sv. Anselma a jeho přijetím některými slovanskými teology. ${ }^{67}$ K tehdejší dobové české teologie můžeme říci, že ze Salajky čerpala více nebo méně do roku 1950. Ovšem nijak zásadní recepce jeho teologického myšlení v tehdejší době zřejmě neproběhla. Po komunistickém nástupu k moci a s tím souvisejícím omezením publikační i vědecké činnosti se o nějaké větší recepci již nedá mluvit. Jak jsme

64 Srov. CDČT, fond AS V - Varia, kt. 3, sl. CMBF: rukopisný návrh na zřízení, zaměření, i organizaci Ústavu pro studium křestanského Východu při Bohoslovecké fakultě v Praze ze dne 9. 8. 1956.

65 Srov. SALAJKA, Antonín. Velehradské; upraveně KASALAJ, Anton. Das cyrillo-methodianische Velehrad und seine Unionskongresse. In Slovak studies XII. Cyrillo methodiana 2, Cleveland-Roma, Slovac Institute, 1972, s. 153-192.

66 Upozorňujeme, že v Emauzích se v jubilejním svatováclavském roce 1929 konal na popud Akademie velehradské vědecký kongres, jehož příspěvky později vyšly i tiskem viz Acta Conventus Pragensis pro studiis orientalibus a. MCMXXIX celebrati. Olomouc 1930.

67 Srov. GORDILLO, Mauricius. Compendium theologiae orientalis. Editio tertia, Roma: PIO, 1950, s. 146, pozn. 2. 
uvedli, po tomto datu Salajka tematiku východního křestanství více méně opustil.

Z rešerší současné teologické produkce pak vyplývá, že si jeho děl všímají tvůrci komentovaných bibliografií české teologické literatury, přičemž zůstávají u výčtu děl, v některých případech u krátké anotace, ${ }^{68} \mathrm{v}$ poměrně malém počtu se výslovně Salajkovy texty parafrázují, ba někdy i citují. ${ }^{69}$ Zásadní se tak jeví skutečnost, že v monumentálním Encyklopedickém slovniku krestanského Východu (obohaceném oproti původní italské verzi o 555 nových hesel) čtenář nalezne biografické heslo k našemu autorovi z pera prof. Pavla Ambrose. ${ }^{70}$

V našem příspěvku jsme se pokusili prof. Salajku představit, jako znalce a propagátora studia křestanského Východu. Všimli jsme si jeho příspěvků k poznání východního křestanství a jeho teologie, popsali jsme také jeho metodu tohoto studia. Vedle znalosti dějin východních církví, jejich liturgie a zbožnosti, kladl nemenší důraz mj. také na dokonalé poznání věroučných problémů a jejich řešení v soudobé teologické literatuře orthodoxních i katolických autorů. Zdůrazňoval také znalost historických reálií o východním rozkolu, vč. poznání ruské a řecké historické a teologické interpretace. „Přehlédneme-li dějiny církevniho rozkolu, můžeme $v$ nich nalézti poučeni vzhledem $k$ obnovení církevní jednoty. Rozdèlení bylo pripravováno staletým rozdẻlením mysli a srdcí, jež časem vzrůstalo, nedostatkem vzájemného porozuméní, mícháním záležitostí politických do záležitostí náboženských, nenávistí nacionální a osobnimi ambicemi. Chceme-li pripravovat cestu k návratu odloučených východnich křestanů, musime jíti cestou opačnou. Musíme presvédčiti obě strany, aby se lépe poznaly a sobě porozumnèly; musíme mít na žreteli (při pevném dogmatickém stanovisku) starobylé obyčeje

68 Srov. POSPÍŠIL, Ctirad V. Česká trinitární teologie a její kontext v letech 1800-2005. Komentovaná bibliografická sonda do dějin české teologie. Theologická revue 2005, roč. 76, č. 2, s. 123-167; POSPÍŠIL, Ctirad V. Jako v nebi, tak i na zemi. Náčrt trinitárni teologie. Praha - Kostelní Vydří: Krystal OP - Karmelitánské nakl., 2009, s. 59, 363; POSPÍŠIL, Ctirad V. Česká trinitární teologie. In FARRUGIA, Edward G. (ed.). Encyklopedický slovnik, s. 242-245; AMBROS, Pavel. Svoboda, s. 637, 673, 779, 798, 803.

69 Srov. SLÁDEK, Karel. Vladimír Solovjov: mystik a prorok. Osobnost a dilo Vladimíra Solovjova pohledem (nejen) české reflexe. Olomouc: Refugium, 2009, s. 39-40, 113-115, 175; SLÁDEK, Karel. Mystická teologie východoslovanských krestanů. Červený Kostelec: Pavel Mervart, 2010, s. 62-63, 92; AMBROS, Pavel. Svoboda, s. 638; AMBROS, Pavel. Česká teologie, spiritualita a křestanský Východ. In FARRUGIA, Edward G. (ed.). Encyklopedický slovnik, s. 229-242.

70 Srov. AMBROS, Pavel. Salajka Antonín (1901-1975). In FARRUGIA, Edward G. (ed.). Encyklopedický slovnik, s. 800. 
a tradice; musíme hledati to, co nás spojuje, nikoliv, co nás rozdèluje; musíme nabádat obě strany $k$ tomu, aby se milovaly $v$ Kristu. ${ }^{771}$

Není problematické pokládat Antonína Salajku za duchovního syna Velehradu. Zvláště když vědomě propojoval cyrilometodějskou tradici se snahou o sjednocení církví a neméně pak, když se sám k této tradici hlásil. V poválečném politickém vývoji četl velikou příležitost všemu slovanstvu. Vždyt' jednou z vítězných mocností druhé světové války byl Svaz sovětských socialistických republik. Studium křestanského Východu tím nabylo klíčového důvodu: znalosti ruské kultury a jazyka.

Čtenáře jsme seznámili s jednou z postav českých katolických znalců křestanského Východu 20. století. Dogmatický teolog, který své badatelské místo a vědecký úkol viděl ve snaze odčinit hřích rozkolu. Budiž z tohoto úhlu pohledu jeho dílo čteno, a necht' my jsme velkorysými čtenáři prací těchto synů své doby.

\section{ABSTRACT \\ LUKÁŠ NOSEK \\ Antonín Salajka's conception of the study of the Christian East}

This article is about Antonín Salajka (1901-1975). This author was the first czech catholic priest laureated in Pontifical Institute of Oriental Studies in Rome (in 1930). Our paper first presents Antonín Salajka's life and then introduces his work. The aim is on the Christian East, as half of his scientific work focused on this theme (cca 280 item). Next, our effort in this article aims at a detailed analysis of author's conception and reasons for the study of the Christian East. He related his study to a great extent to the study of church Slovanic. The fundamental elements of Salajka's conception were: (1) history of orthodox churches, variety of orthodox liturgical traditions, reasons for the so called East-West schism of 1054; (2) deeper knowledge of orthodox theology in a so-called comparative dogmatic theology; (3) introduction of his endeavour towards unification of all christian churches. Finally this article presents Salajka' project aimed at the establishment of Institute for study of the Christian East in the 1940s in Prague.

\section{Key words}

Pontificio Istituto Orientale, Christian East, conception of the study of the Christian East, unionism of Velehrad, ecumenism

71 SALAJKA, Antonín. Úvod do studia krestáanského východu, s. 29. 